\title{
Novorojenčki, rojeni kot veliki za gestacijsko starost: vzroki in posledice
}

\section{Large-for-gestational-age newborns: causes and consequences}

Mojca Železnik,

Aneta Soltirovska Šalamon

\section{Izvleček}

Novorojenčki, rojeni kot veliki za gestacijsko starost, so novorojenčki, ki se rodijo s porodno težo in/ali porodno dolžino nad 90. percentilom za gestacijsko starost in spol. Neoptimalno znotrajmaternično okolje preko epigenetskih mehanizmov vpliva na fenotipske spremembe presnovnih in endokrinih poti pri plodu. Čezmerna rast ploda vodi v prenatalne in postnatalne zaplete, kot so prezgodnji porod, obporodna hipoksija, poškodbe, prehodne presnovne motnje, policitemija in zlatenica. Dolgoročno čezmerna rast ploda pomeni povečano tveganje za razvoj presnovnih in srčno-žilnih bolezni ter motenj delovanja osrednjega živčevja.

Etiološko najpomembnejši vzrok makrosomije je nosečniška sladkorna bolezen. Če se pojavi po 28. tednu nosečnosti, lahko ostane neprepoznana, saj aktivno iskanje sladkorne bolezni pri nosečnicah poteka pred tem.

Ključne besede: dolgoročni zdravstveni izidi, makrosomija, nosečniška sladkorna bolezen, novorojenček, velik za gestacijsko starost. 


\section{Uvod}

Plod $v$ maternici raste eksponentno hitro, saj $95 \%$ svoje telesne mase pridobi $v$ drugi polovici nosečnosti. Na njegovo rast vplivajo genetski in okoljski dejavniki, dejavniki, povezani z zdravjem in prehrano matere, ter dejavniki, povezani z maternico in posteljico $(1,2)$. Čezmerna rast ploda vodi v makrosomijo. Novorojenček se rodi $z$ večjimi porodnimi merami, kot bi pričakovali glede na njegovo genetsko zasnovo $(2,3)$. Govorimo o novorojenčku, velikem za gestacijsko starost (angl. large for gestational age, LGA), pri katerem sta porodna teža in/ali porodna dolžina nad 90 . percentilom za gestacijsko starost in spol (2).

$\checkmark$ literaturi za opredelitev velikosti novorojenčkov poleg standarnih antropometričnih meritev uporabljamo tudi ponderialni indeks $\left(\mathrm{g} / \mathrm{cm}^{3}\right)$, $\mathrm{ki}$ ne razlikuje med deležem maščevja in suhe telesne mase. Vse večji pomen pri opredelitvi, ali ima novorojenček prevelike porodne mere za gestacijsko starost, pripisujejo neposrednim tehnikam za določitev telesne sestave in neonatalne adipoznosti, kot sta dvoenergijska rentgenska denzitometrija in pletizmografija (3).

Prekomerna rast ploda je simetrična, ko vse telesne mere presegajo 90 . percentil za gestacijsko starost in spol. $V$ tem primeru so največkrat $v$ ozadju genetski dejavniki. Na drugi strani je prekomerna rast ploda lahko asimetrična, največkrat pri otrocih mater z nosečniško sladkorno boleznijo (NSB). Pri teh otrocih rast možganov ni povečana, imajo pa več telesnega maščevja, mišične mase in organomegalijo $(4,5)$. $V$ literaturi navajajo, da je pogostnost LGA novorojenčkov v populaciji $10 \%(3,6)$; pri NSB je pogostnost le te $15-45 \%$, kar je trikrat več, kot v normalno razporejeni populaciji (5).

Pomemben in neodvisen dejavnik je tudi povečan indeks telesne mase (ITM) pri materi, saj imajo debele matere kar dvakrat večjo verjetnost za rojstvo LGA novorojenčka kot matere z normalno telesno maso (5).

$\checkmark$ nadaljevanju opisujemo etiološke in patofiziološke mehanizme nastanka LGA ter klinične posebnosti novorojenčkov, velikih za gestacijsko starost, s poudarkom na dolgoročnem izidu.

\section{Etiologija}

Pospešena rast ploda je posledica povečane dostave hranil, ki lahko nastopi zaradi delovanja genetskih in okoljskih dejavnikov ali njihove kombinacije (2).

Dejavniki, ki povzročajo prekomerno rast ploda, so lahko konstitucijski (družinski vzorec, sorojenec, rojen kot LGA), dejavniki s strani matere (npr. povišana vrednost ITM, prekomeren prirast telesne mase $v$ nosečnosti, višja starost matere in večrodnost) $(4,7,8)$.

Pomemben dejavnik, ki vpliva na rast ploda, je prekomerna telesna masa ali debelost matere (ITM $>25 \mathrm{~kg} / \mathrm{m}^{2}$ ) $(9,10)$. Izsledki raziskav kažejo, da manjši prirast telesne mase nosečnic s sicer povišanim ITM na rast ploda deluje zaščitno (11), medtem ko slabo nadzorovana NSB mater s povišanim ITM pomeni večje tveganje za slabši neonatalni izid v primerjavi z materami z NSB in normalnim ITM (9).

Če ima novorojenček poleg prevelikih telesnih mer ob rojstvu tudi nepravilnosti drugih organov in organski sistemov ali dismorfna znamenja, je lahko v ozadju sindromska bolezen (npr. Beckwith-Wiedemannov sindrom, Pallister -Killianov sindrom, Sotosov sindrom, Perlmanov sindrom, Weaverjev sindrom, Simpson-Golabi-Behmelov sindrom itd.) (7).

Najpogostejši dejavnik, ki vpliva na čezmerno rast ploda, je neurejena sladkorna bolezen pri materi, predvsem NSB, pa tudi sladkorna bolezen tipa 1 in tipa 2 z začetkom pred nosečnostjo $(1,2,12)$.

\section{Patofiziologija}

Rast ploda je kompleksen proces, $v$ katerem gre za interakcijo med materjo, plodom in posteljico, vključeni pa so tudi genetski, presnovni in endokrini dejavniki. Patofiziologijo makrosomije lahko pojasnimo s Pedersonovo hipotezo (5): če je materin glikemični nadzor okvarjen, lahko glukoza prehaja preko posteljice, medtem ko inzulin posteljice ne prehaja $(4,5)$. $V$ drugem trimesečju plodova trebušna slinavka odgovori na hiperglikemijo tako, da prične avtonomno izločati inzulin $(3,5,13)$. Ob prevladi anabolnih hormonov je pospešena znotrajmaternična rast, povišana je aktivnost jetrnih encimov, povečajo se zaloge maščob in beljakovin, $v$ jetrih pa je povišana vsebnost glikogena $(4,9,13)$.

\section{Opredelitev nosečniške sladkorne bolezni}

NSB je "katera koli glukozna intoleranca z začetkom v nosečnosti oziroma prvič diagnosticirana v nosečnosti" $(9,14)$. Diagnozo postavimo z meritvijo glukoze na tešče ali v naključnem vzorcu in z določitvijo glukoze po obremenilnem glukoznem tolerančnem testu med 24. in 28. tednom nosečnosti. Po priporočilih Svetovne zdravstvene organizacije (SZO) diagnozo NSB postavimo, če je dosežena ali presežena vsaj ena diagnostična vrednost, in sicer vrednost glukoze na tešče $\geq$ $5,1 \mathrm{mmol} / \mathrm{loz}$. $\geq 10 \mathrm{mmol} / \mathrm{l}$ eno uro po obremenitvi s $75 \mathrm{~g}$ glukoze oz. po dveh urah $\geq 8,5 \mathrm{mmol} / \mathrm{l}$ (16). Diagnostični problem nastopi, če se NSB pojavi po 28. tednu nosečnosti, ko prav tako vpliva na rast in razvoj ploda, a lahko ostane neprepoznana (14). Glede na rezultate raziskave, ki so jo opravili Jovanovic-Peterson in sodelavci ter $v$ katero je bilo vključenih 323 nosečnic z NSB in 361 v kontrolni skupni, porodna teža najbolje korelira s postprandialno ravnijo glukoze $v$ drugem in tretjem trimesečju (17). Medtem ko je glikozilirani hemoglobin (HbA1c) referenčni test za dolgotrajno spremljanje urejenosti bolezni in ravni glukoze, pa 
glikozilirani albumin (GA) odraža kratkotrajno glikemijo in bi ga prav tako lahko uporabljali za presejanje in spremljanje nosečnic z NSB (18).

\section{Klinična slika v novorojenčkovem obdobju}

Čezmerna plodova rast vodi v prenatalne in postnatalne zaplete, torej vpliva na rast in razvoj novorojenčka in otroka ter na razvoj bolezni v odraslosti (3). Na pospešeno rast ploda najbolj vplivajo epizodične hipoglikemije pri materi, ki se pojavljajo navadno po obroku (pulzatilna hiperglikemija), saj pri plodu spodbujajo izločanje inzulina (12) particularly as type 2 diabetes continues to increase worldwide. Despite advances in perinatal care, infants of diabetic mothers (IDMs. Matere z znano sladkorno boleznijo zato največkrat podrobneje spremljamo, da imajo bolj urejene vrednosti glukoze (13).

Dokazali so, da hiperglikemija pred zanositvijo in v zgodnji nosečnosti vpliva na razvoj organov ter poveča verjetnost razvoja prirojenih nepravilnosti možganov, srčno-žilnega sistema (srčnih anomalij) ter ledvic in skeleta pri plodu $(5,12)$. Šestnajstkrat pogostejše so nepravilnosti osrednjega živčevja, nepravilnosti v zapiranju nevralne cevi (anencefalija, encefalokela, meningomielokela) in sindrom kavdalne regresije (12).

LGA novorojenčki se pogosteje rodijo prezgodaj, utrpijo perinatalno hipoksijo in imajo obporodne poškodbe. Zastoj poroda zaradi zastoja ramen lahko povzroči zlom ključnice ali dolgih kosti $(11,15,19)$. Tveganje pareze brahialnega pleteža je pri porodni teži nad 4500 gramov dvajsetkrat večje (5).

Najpogostejši zaplet LGA novorojenčkov v prvih urah po rojstvu je hipoglikemija. Po rojstvu je namreč preskrba z glukozo preko posteljice nenadno prekinjena, pri čemer ima novorojenček visoke endogene kon- centracije inzulina (5). Hiperinzulinemija neposredno zavre glikogenolizo in glukoneogenezo ter tudi sproščanje prostih maščobnih kislin iz maščobnih tkiv, zato jih ne morejo uporabiti kot alternativni vir energije za oksidativno presnovo (9). Pojavijo se lahko tudi druge presnovne motnje in elektrolitska neravnovesja, najpogosteje hipokalcemija in hipomagnezemija $(9,12)$. Inzulin in inzulinu podobni rastni dejavniki povečajo nastajanje rdečih krvnih celic, sekundarna posledica povečane eritropoeze pa je lahko trombocitopenija $(9,12)$. Policitemija lahko vodi v nastanek hiperviskoznega sindroma in hiperbilirubinemije $(5,9,12)$.

Hiperinzulinemija se vpleta tudi v presnovo glukortikoidov, s čimer upočasni sintezo surfaktanta. Zato imajo LGA novorojenčki vse do 38 . tedna nosečnosti šestkrat večjo verjetnost pomanjkanja surfaktanta in bolezen hialinih membran (12). Povečana vsebnost glikogena v jetrih, ledvicah, skeletnih mišicah in srcu vodi v organomegalijo $(5,12)$. Povečano nalaganje glikogena in maščob v kardiomiocitih lahko povzroči prehodno hipertrofično kardiomiopatijo, največkrat intraventrikularnega septuma, redkeje celotnega miokarda (12).

\section{Presnovne posledice}

Epidemiološke raziskave v zadnjih tridesetih letih so pokazale, da so rastni vzorci otrok, rojenih LGA, v prvih mesecih in letih življenja dejavnik tveganja za razvoj presnovnega sindroma, vključujoč debelost in sladkorno bolezen tipa 2, ter za srčno-žilne bolezni in maligne bolezni, kot so levkemija, rak dojk, prostate in kolona $(3,20,21)$. Preplet genetskih mehanizmov, epigenetskih mehanizmov in dejavnikov okolja povzroči moteno presnovno in energijsko ravnovesje, ki se prenaša iz generacije $v$ generacijo $(5,13,20)$.

Neoptimalno znotrajmaternično okolje preko epigenetskih mehanizmov vpliva na fenotipske spremembe pre- snovnih in endokrinih poti ploda (5). Ugotovili so, da so imeli LGA otroci, rojeni materam z NSB, že v zgodnjem otroštvu povečno maščobno maso in $\mathrm{s}$ tem tudi večje tveganje debelosti kasneje v življenju $(3,5)$. Približno $20 \%$ otrok, rojenih kot LGA, v prvem letu življenja vztraja na višji percentilni krivulji. Pri njih so dokazali epigentske modifikacije, s katerimi bi lahko pojasnili višjo porodno težo in spremenjeno telesno sestavo (3). Najnovejše raziskave odkrivajo odklone epigenetskih mehanizmov, povezanih z metilacijo DNK in modifikacijo histonov, ki motijo celični cikel in vplivajo na izražanje genov v odraslosti $(5,13,20)$. Znano je, da gena, na primer IGF2 in H19, vplivata na rast ploda, zato lahko epigenetske spremembe teh genov vodijo v spremenjeno rast; tako npr. hipometilacija povzroča zmanjšano izraženje IGF2, kar povzroči prenatalni in postnatalni zastoj rasti (v $30 \%$ primerov Silver-Russellovega sindroma), medtem ko hipermetilacija povzroči prekomerno izražanje IGF2, kar vodi $v$ čezmerno rast (Beckwith-Wiedemannov sindrom) (21).

Pomembna epigenetska modifikacija za razvoj fenotipa LGA je hipermetilacija specifičnih genskih lokusov za fibroblastni rastni receptor 2 (FGFR2), ki sodeluje pri modulaciji regulacije in zorenja celic $(3,21)$. Neoptimalno znotrajmaternično okolje in prekomerna izpostavljenost hranilom vodita $v$ metilacijo genov, pomembnih pri razvoju debelosti, kar vpliva na razvoj in funkcijo adipocitov (večja sposobnost za shranjevanje energije in ustvarjanje novih celic v maščobnem tkivu). Predvidevajo torej, da imajo novorojenčki, rojeni kot LGA, ki vztrajajo na višji rastni krivulji, zaradi epigenetskih sprememb metabolnih genov, t.i. genov, pomembnih pri razvoju debelosti, tudi v dojenčkovem obdobju spremembe $v$ številu in velikosti adipocitov (3).

Chiavaroli in sodelavci so $v$ raziskavi vzorca LGA novorojenčkov, rojenih materam, ki niso imele NSB, ugotavlja- 
li upočasnitev rasti (angl. catch-down growth) po rojstvu $(3,21)$. Otroci so bili pri šestih in dvanajstih mesecih glede na antropometrične meritve podobni novorojenčkom s primernimi porodnimi merami (10. - 90. percentil) za gestacijsko starost in spol (21). Menijo, da je znotrajmaternična čezmerna rast posledica energijsko bogatega plodovega okolja, po rojstvu, ko tega okolja ni več, pa prevladajo vplivi genetsko določenega potenciala rasti. Ugotovili so tudi, da med LGA novorojenčki in novorojenčki s primernimi porodnimi merami ni bilo epigenetskih razlik v metilaciji genoma $(3,21)$. Podobno so ugotovili tudi Tall in sodelavci - da so imeli otroci, rojeni kot LGA, ki so po rojstvu počasneje pridobivali težo, v otroštvu manj podkožnega maščevja in nižji ITM kot novorojenčki, ki so se rodili kot LGA in so imeli po rojstvu pospešeno rast (22).

Rezultati raziskav kažejo tudi, da imajo novorojenčki, rojeni kot LGA, višjo inzulinsko rezistenco kot novorojenčki s primernimi porodni merami ter da se rezistenca od otroštva do adolescence še povečuje (23). V danski kohortni raziskavi, v katero je bilo vključenih 9134 dečkov, ugotavljajo, da so imeli dečki s porodno težo nad $4000 \mathrm{~g}$ in z ITM pod $25 \mathrm{~kg} / \mathrm{m}^{2}$ v starosti 19 let povečano tveganje za koronarno srčno bolezen (24).

Zdi se torej, da zgolj večja porodna teža ni zadosten dejavnik tveganja za dolgoročne presnovne zaplete. Poleg natančnih antropometričnih meritev in telesne sestave igra namreč pomembno vlogo etiologija povečane rasti. Podrobnejšo opredelitev dolgoročnih zdravstvenih tveganj bi omogočile analize, v katerih bi upoštevali vse navedene dejavnike (3).

\section{Nevrološke posledice}

Iz t. i. hipoteze o prehrani in razvoju ploda izhaja, da sta pravilni prenatalna in postnatalna prehrana bistvenega pomena za optimalen razvoj in delovanje osrednjega živčevja (13). Razlogov za domneve, da imajo otroci, rojeni kot LGA, lahko slabši nevrološki in kognitivni razvoj kot otroci, rojeni s primernimi merami za gestacijsko starost, je več. Dokazano je, da se najpomembnejša etiološka dejavnika čezmerne rasti ploda - NSB in debelost matere - preko hormonskega neravnovesja, zvišane ravni vnetnih citokinov in oksidativnega stresa vpletata $v$ razvoj osrednjega živčevja pri plodu $(25,26)$. Prekomeren vnos hranil vodi do presnovnih sprememb, porasta ravni leptina in estrogena ter do inzulinske rezistence. Inzulin in inzulinu podobni rastni dejavniki vplivajo na diferenciacijo nevronov in izgradnjo nevritov (27). Otroci mater z NSB so izpostavljeni presnovnemu okolju, ki vključuje visoke ali nihajoče koncentracije glukoze, in potencialni ketonemiji, kar bi lahko vplivalo na strukturne spremembe možganov $(13,28)$. Na razvoj nevronov pomembno vpliva tudi pomanjkanje železa v razvijajočem se osrednjem živčevju, saj je zaradi povišane eritropoetske aktivnosti večja poraba železa v jetrih in kostnem mozgu (12). Nenazadnje na razvoj živčevja vplivajo tudi zapleti med nosečnostjo in ob porodu (hipoksija) ter že omenjeni zapleti v neonatalnem obdobju, ki so pogostejši pri LGA novorojenčkih $(25,26)$.

LGA novorojenčki so lahko po rojstvu brez abnormnih nevroloških znakov, lahko pa ob nevrološkem spremljanju opazimo motnje čuječnosti (letargija, razdražljivost), cvileč jok, motnje mišičnega tonusa (hipotonija oz. hipertonija) in oslabljen sesalni refleks (9). Raziskav, v katerih bi proučevali njihov nevrološki razvoj v kasnejših obdobjih, je malo.

Ugotovili so, da imajo otroci, rojeni kot LGA, pogosteje socialne (29) in vedenjske težave (25) ter povečano tveganje za avtizem (30). Matere s pridruženimi presnovnimi stanji (hipertenzija, sladkorna bolezen in debelost) imajo večkrat potomce $z$ avtističnim spektrom in razvojnim zaostankom (31). Obstajajo tudi raziskave, v katerih niso dokazali da bi otroci, rojeni kot LGA, v predšolskem obdobju imeli pogosteje govorne in vedenjske težave (26). Podobno tudi v veliki prospektivni kohortni raziskavi niso dokazali razlik v kognitivnih funkcijah med otroki, rojenimi LGA, in otroki, ki so bili rojeni s primernimi porodnimi merami (32).

V raziskavah, v katere so vključili otroke mater z NSB, ugotavljajo, da imajo ti otroci manjšo zmožnost habituacije na zvočne dražljaje, nižje dosežke na psiholoških testiranjih, nižji inteligenčni količnik (IQ), težave na področju govora in motoričnega razvoja ter motnje vedenja, čustvovanja, pozornosti in hiperaktivnosti (33-36). Ornoy in soavtorji so v skupini 32 otrok mater z NSB ugotovili pogostejše motnje razvoja fine in grobe motorike kot v skupini otrok mater brez NSB (37).

S preučevanjem nevrofizioloških funkcij so ugotovili, da imajo otrocih mater z NSB zapoznelo zorenje vidnih izzvanih potencialov (38). Castro Conde in sodelavci so preučevali zorenje osnovne električne aktivnosti v elektroencefalografskem zapisu teh otrok in ugotavljali večji delež nezrelih vzorcev, predvsem večji delež prehodnih ostrih valov, ki nakazujejo subakutno oz. kronično poškodbo osrednjega živčevja (31).

V številnih raziskavah so proučevali kognitivne sposobnosti potomcev mater z NSB in poročali o slabših rezultatih pri predšolskih otrocih (38). Še bolj pomembni so verjetno zaključki tovrstnih raziskav pri starejših otrocih, v katerih so ugotavljali neposreden vpliv na izobraževalne in poklicne rezultate $(39,40)$. Vsekakor pa moramo poudariti, da v raziskavah niso upoštevali drugih spremenljivk, ki pomembno vplivajo na celostni izid otrok, npr. izobrazbo staršev, socialni, finančni in zakonski status družine ter interakcijo med starši in otrokom (26). 


\section{Zaključek}

Rezultati številnih raziskav kažejo, da so LGA novorojenčki izpostavljeni večjemu tveganju za dolgoročno presnovno obolevnost, predvsem za razvoj debelosti. Med napovednimi dejavniki so najpomembnejši etiološki, predvsem NSB in debelost matere. Otroci, ki čezmerno rastejo tudi v dojenčkovem obdobju, imajo večje in številnejše maščobne celice in tudi epigenetske spremembe genov, pomembnih pri razvoju debelosti. Rezultati raziskav o srčno-žilnih izidih pri odraslih, rojenih kot LGA, izpostavljajo predvsem pomen znotrajmaterničnega in postnatalnega okolja. Za oceno drugih razsežnosti otrokovega nevrokognitivnega razvoja bi bile potrebne nadaljnje raziskave.

\section{Literatura}

1. Rigo J, Mohamed MJ, Curtis M. Diabetic pregnancy. In: Fanaroff and Martin's Neonatal -perinatal medicine: Diseases of the fetus and infant. Mosby, Inc., an affiliate of Elsevier; 2011.

2. Jan M Hawdon. Neonatal complications following diabetes in pregnancy. In: Rennie and Roberton's Textbook of Neonatology. London. Churchill Livingstone; 2012. p. 387-94.

3. Chiavaroli V, Derraik JGB, Hofman PL, Cutfield WS. Born Large for Gestational Age: Bigger Is Not Always Better. J Pediatr 2016; 170: 307-11.

4. Glodean DM, Miclea D, Popa AR. Macrosomia. A Systematic Review of Recent Literature. Rom J Diabetes, Nutr Metab Dis 2018; 25(2): 187-95.

5. Kc K, Shakya S, Zhang H. Gestational diabetes mellitus and macrosomia: A literature review. Ann Nutr Metab 2015; 66: 14-20.

6. Beta J, Khan N, Khalil A, Fiolna M, Ramadan G, Akolekar R. Maternal and neonatal complications of fetal macrosomia: systematic review and meta-analysis. Ultrasound Obstet Gynecol 2019; 54(3): 308-18

7. Vora N, Bianchi DW. Genetic considerations in the prenatal diagnosis of overgrowth syndromes. Prenat Diagn 2009; (May): 923-9.

8. Rezaiee M, Aghaei M, Mohammadbeigi A, Farhadifar F, zadeh Ns, Mohammadsalehi N. Fetal macrosomia: Risk factors, Maternal, and Perinatal outcome. Ann Med Health Sci Res 2013; 3(4): 546.

9. Mitanchez D. What neonatal complications should the pediatrician be aware of in case of maternal gestational diabetes? World J Diabetes 2015; 6(5): 734.

10. Tul N, Lučovnik M, Verdenik I. Povezava med telesno maso ob zanositvi, med nosečnostjo in izidi nosečnosti pri nosečnicah v Sloveniji. V: Klinična prehrana v nosečnosti. Ljubljana: Center za razvoj poučevanja, Medicinska fakulteta; 2015. str. 412-24.

11. Viecceli C, Remonti LR, Hirakata VN, Mastella LS, Gnielka V, Oppermann MLR, et al. Weight gain adequacy and pregnancy outcomes in gestational diabetes: a meta-analysis. Obes Rev 2017; 18(5): 567-80

12. Hay WW. Care of the infant of the diabetic mother. Curr Diab Rep 2012; 12(1): 4-15.

13. Fraser A, Lawlor DA. Long-term health outcomes in offspring born to women with diabetes in pregnancy. Curr Diab Rep 2014; 14(5).

14. Metzger BE. International Association of Diabetes and Pregnancy Study Groups recommendations on the diagnosis and classification of hyperglycemia in pregnancy. Diabetes Care 2010; 33(3): 676-82

15. Hartling L, Dryden DM, Guthrie A, Muise M, Vandermeer B, Donovan L. Diagnostic thresholds for gestational diabetes and their impact on pregnancy outcomes: A systematic review. Diabet Med 2014; 31(3): 319-31.

16. World Health Organization. Diagnostic criteria and classification of hyperglycemia first detected in pregnancy. Geneva, Switzerland: World Health Organization. 2013.

17. Jovanovic-Peterson L, Peterson CM, Reed GF Metzger BE, Mills JL, Knopp RH, et al. Maternal postprandial glucose levels and infant birth weight: The Diabetes in Early Pregnancy Study Am J Obstet Gynecol 1991; 164(1 PART 1): 103-11

18. Hiramatsu Y, Shimizu I, Omori Y, Nakabayashi M. Determination of reference intervals of glycated albumin and hemoglobin A1c in healthy pregnant Japanese women and analysis of their time courses and influencing factors during pregnancy. Endocr J. 2012; 59(2): 145-51.

19. van Zijl MD, Oudijk MA, Ravelli ACJ, Mol BWJ, Pajkrt E, Kazemier BM. Large-for-gestational-age fetuses have an increased risk for spontaneous preterm birth. J Perinatol 2019; Available from: http://dx.doi.org/10.1038/ s41372-019-0361-6

20. Filiberto AC, Maccani MA, Koestler D, Wilhelm-Benartzi C, Avissar-Whiting M, Banister CE, et al. Birthweight is associated with DNA promoter methylation of the glucocorticoid receptor in human placenta. Epigenetics 2011; 6(5): 566-72 21. Chiavaroli V, Cutfield WS, Derraik JGB, Pan Z, Ngo S, Sheppard A, et al. Infants born largefor-gestational-age display slower growth in early infancy, but no epigenetic changes at birth. Sci Rep 2015; 5(August): 1-8.

22. Taal HR, Vd Heijden AJ, Steegers EAP, Hofman A, Jaddoe VWV. Small and large size for gestational age at birth, infant growth, and childhood overweight. Obesity 2013; 21(6): 1261-8. 23. Chiavaroli V, Marcovecchio ML, De Giorgis T, Diesse L, Chiarelli F, Mohn A. Progression of cardio-metabolic risk factors in subjects born small and large for gestational age. PLoS One 2014; 9(8): 1-7.

24. Osler M, Lund R, Kriegbaum M, Andersen AMN. The influence of birth weight and body mass in early adulthood on early coronary heart disease risk among Danish men born in 1953. Eur J Epidemiol 2009; 24(1): 57-61.

25. Van Lieshout RJ, Boyle MH. Canadian youth born large or small for gestational age and externalizing and internalizing problems. Can J Psychiatry 2011; 56(4): 227-34

26. Frank CE, Speechley KN, Macnab JJ,

Campbell MK. Infants Born Large for Gestational Age and Developmental Attainment in Early Childhood. Int J Pediatr 2018; 2018: 1-7.

27. Van Mil NH, Steegers-Theunissen RPM, Motazedi E, Jansen PW, Jaddoe VWV, Steegers $E A P$, et al. Low and high birth weight and the risk of child attention problems. J Pediatr 2015; 166(4): 862-869.e3.

28. Gin $H$, Vambergue $A$, Vasseur $C$, Rigalleau $V$, Dufour $\mathrm{P}$, Roques $\mathrm{A}$, et al. Blood ketone monitoring: A comparison between gestational diabetes and non-diabetic pregnant women. Diabetes Metab 2006; 32(6): 592-7.

29. Alati R, Najman JM, O'Callaghan M, Bor W, Williams GM, Clavarino A. Fetal growth and behaviour problems in early adolescence: Findings from the Mater University Study of Pregnancy. Int J Epidemiol 2009; 38(5): 1390-400.

30. Moore GS, Kneitel AW, Walker CK, Gilbert WM, Xing G. Autism risk in small- and large-forgestational-age infants. Am J Obstet Gynecol 2012; 206(4): 314.e1-314.e9. Available from: http://dx.doi.org/10.1016/j.ajog.2012.01.044 31. Conde JRC, González NLG, Barrios DG, Campo CG, Hernández YS, Comino ES. Video-EEG recordings in full-term neonates of diabetic mothers: Observational study. Arch Dis Child Fetal Neonatal Ed 2013; 98(6): 3-8.

32. Paulson JF, Mehta SH, Sokol RJ, Chauhan SP. Large for gestational age and long-term cognitive function. Am J Obstet Gynecol 2014; 210(4): 343.e1 - 4.

33. Grissom NM, Reyes TM. Gestational overgrowth and undergrowth affect neurodevelopment: Similarities and differences from behavior to epigenetics. Int J Dev Neurosci 2013; 31(6): 406-14.

34. Gonzalez-Gonzalez NL, Medina V, Padron E, Domenech E, Diaz Gomez NM, Armas H, et al. Fetal and Neonatal Habituation in Infants of Diabetic Mothers. J Pediatr 2009; 154(4): 492-7. 35. Cordón IM, Georgieff MK, Nelson CA. Neural correlates of emotion processing in typically developing children and children of diabetic mothers. Dev Neuropsychol 2009; 34(6): 683-700

36. Dionne G, Boivin M, Séguin JR, Pérusse D, Tremblay RE. Gestational diabetes hinders language development in offspring. Pediatrics 2008; $122(5)$.

37. Ornoy A, Ratzon N, Greenbaum C, Peretz E, Soriano D, Dulitzky M. Neurobehaviour of school age children born to diabetic mothers. Arch Dis Child Fetal Neonatal Ed 1998; 79(2).

38. Brinciotti M, Matricardi M, Colatrella A, Torcia F, Fallucca F, Napoli A. Visual evoked potentials in infants of diabetic mothers: Relations to clinical and metabolic status during pregnancy and delivery. Clin Neurophysiol 2009; 120(3): 563-8. 39. Clausen TD, Mortensen EL, Schmidt L, Mathiesen ER, Hansen T, Jensen DM, et al. Cognitive Function in Adult Offspring of Women with 
Gestational Diabetes-The Role of Glucose and Other Factors. PLoS One 2013; 8(6): 2-9.

40. Dahlquist G, Källén B. School marks for Swedish children whose mothers had diabetes during pregnancy: A population-based study. Diabetologia 2007; 50(9): 1826-31.

\section{Mojca Železnik}

Klinični oddelek za neonatologijo, Univerzitetni klinični center Ljubljana Ljubljana, Slovenija

doc. dr. Aneta Soltirovska Šalamon, dr. med.

(kontaktna oseba / contact person)

Klinični oddelek za neonatologijo

Pediatrična klinika, Univerzitetni klinični center

Bohoričeva 20, Ljubljana, Slovenija telefon: 015229274 / 9630

e-naslov: aneta.soltirovska@kclj.si

prispelo / received: 11. 4. 2020

sprejeto / accepted: 2. 6. 2020

Železnik M., Soltirovska Šalamon A.

Novorojenčki, rojeni kot veliki za gestacijsko

starost: vzroki in posledice. Slov Pediatr 2020;

27(3): 127-132. https://doi.org/10.38031/

slovpediatr-2020-3-04. 